\title{
Involvement of the Neuropeptide Nociceptin/Orphanin FQ in Kainate Seizures
}

\author{
Gianni Bregola, ${ }^{1,2}$ Silvia Zucchini,, ${ }^{1,2}$ Donata Rodi, ${ }^{1,2}$ Anna Binaschi, ${ }^{1,2}$ Claudio D'Addario, ${ }^{3}$ Daniela Landuzzi, ${ }^{3}$ \\ Rainer Reinscheid, ${ }^{4}$ Sanzio Candeletti, ${ }^{3}$ Patrizia Romualdi, ${ }^{3}$ and Michele Simonato ${ }^{1,2}$ \\ ${ }^{1}$ Department of Clinical and Experimental Medicine, Section of Pharmacology, and ${ }^{2}$ Neuroscience Center, University of \\ Ferrara, 44100 Ferrara, Italy, ${ }^{3}$ Department of Pharmacology, University of Bologna, 40126 Bologna, Italy, and \\ ${ }^{4}$ Department of Pharmacology, University of California at Irvine, Irvine, California 92612
}

The neuropeptide nociceptin/orphanin FQ (N/OFQ) has been shown to modulate neuronal excitability and neurotransmitter release. Previous studies indicate that the mRNA levels for the N/OFQ precursor (proN/OFQ) are increased after seizures. However, it is unclear whether N/OFQ plays a role in seizure expression. Therefore, (1) we analyzed proN/OFQ mRNA levels and NOP (the N/OFQ receptor) mRNA levels and receptor density in the kainate model of epilepsy, using Northern blot analysis, in situ hybridization, and receptor binding assay, and (2) we examined susceptibility to kainate seizure in mice treated with $1-[(3 R$, 4R)-1-cyclooctylmethyl-3-hydroxymethyl-4-piperidyl]-3-ethyl1, 3-dihydro-benzimidazol-2-one (J-113397), a selective NOP receptor antagonist, and in proN/OFQ knock-out mice.

After kainate administration, increased proN/OFQ gene expression was observed in the reticular nucleus of the thalamus and in the medial nucleus of the amygdala. In contrast, NOP mRNA levels and receptor density decreased in the amygdala, hippocampus, thalamus, and cortex. Mice treated with the NOP receptor antagonist $\mathrm{J}-113397$ displayed reduced susceptibility to kainate-induced seizures (i.e., significant reduction of behavioral seizure scores). N/OFQ knock-out mice were less susceptible to kainate seizures compared with their wild-type littermates, in that lethality was reduced, latency to generalized seizure onset was prolonged, and behavioral seizure scores decreased. Intracerebroventricular administration of N/OFQ prevented reduced susceptibility to kainate seizures in N/OFQ knock-out mice.

These data indicate that acute limbic seizures are associated with increased N/OFQ release in selected areas, causing downregulation of NOP receptors and activation of N/OFQ biosynthesis, and support the notion that the N/OFQ-NOP system plays a facilitatory role in kainate seizure expression.

Key words: epilepsy; seizure; nociceptin; opioid receptor like-1; kainate; knock-out mice
Nociceptin/Orphanin FQ (N/OFQ) (Meunier et al., 1995; Reinscheid et al., 1995) is a neuropeptide that activates an orphan receptor of the opioid family, termed ORL-1, OP4, or NOP (Mollereau et al., 1994; Cox et al., 2000). N/OFQ is a 17 amino acid peptide with an $\mathrm{N}$ terminus that shows striking similarities to the mammalian opioid peptides, especially to dynorphin A (Meunier et al., 1995; Reinscheid et al., 1995). Its receptor, cloned using molecular screening methods based on opioid receptor gene sequences (Bunzow et al., 1994; Fukuda et al., 1994; Mollereau et al., 1994; Wang et al., 1994; Wick et al., 1994), also shares a high sequence similarity with opioid receptors, especially with the $\kappa$ subtype. However, a clear pharmacological separation exists between the opioid and the N/OFQ systems (Calò et al., 2000).

In the short time after discovery, various biological functions of N/OFQ in neuronal and non-neuronal tissues have been demonstrated. These include modulation of nociception (Meunier et al., 1995; Reinscheid et al., 1995; Tian et al., 1998), locomotor activity (Reinscheid et al., 1995), stress responses and anxiety (Jenck et

Received June 21, 2002; revised Sept. 5, 2002; accepted Sept. 10, 2002.

This study was supported by grants from the Italian Ministry for the University and Scientific Research (MURST ex60\%, MURST cofin1999, Fondo per gli Investimenti della Ricerca di Base 2001). The technical assistance of Valeria Bragonzoni and Linda Frigati is gratefully acknowledged. We thank Drs. Brian Cox, Remi Quirion, Girolamo Calò, Domenico Regoli, Sergio Ferri, and Lorenzo Beani for their helpful suggestions on this manuscript.

Correspondence should be addressed to Dr. Michele Simonato, Department of Experimental and Clinical Medicine, Section of Pharmacology, University of Ferrara, via Fossato di Mortara, 17-19, 44100 Ferrara, Italy. E-mail: m.simonato@unife.it. Copyright (C) 2002 Society for Neuroscience 0270-6474/02/2210030-09\$15.00/0 al., 1997), and learning and memory (Sandin et al., 1997; Manabe et al., 1998). Moreover, N/OFQ may be implicated in certain types of seizures: (1) the gene encoding the N/OFQ precursor (proN/OFQ) and the NOP gene are constitutively expressed in forebrain areas implicated in limbic seizures, such as amygdala and hippocampus (Neal et al., 1999a,b); (2) kainate-induced seizures dramatically increase proN/OFQ mRNA levels in the thalamic reticular nucleus (Bregola et al., 1999); and (3) N/OFQ modulates neuronal excitability and neurotransmitter release in amygdala (Meis and Pape, 2001), hippocampus (Moran et al., 2000), and cortex (Schlicker and Morari, 2000). However, the possible involvement of N/OFQ in epileptic syndromes has not been firmly established. Despite its homology with dynorphin A, N/OFQ displays anti-opioid effects in the forebrain (Calò et al., 2000): because dynorphin has anti-epileptic effects (Simonato and Romualdi, 1996), N/OFQ might have pro-epileptic effects. However, some cellular actions of N/OFQ, such as inhibition of excitability in the hippocampus (Yu and Xie, 1998; Madamba et al., 1999; Tallent et al., 2001) and of glutamate release in the cortex (Nicol et al., 1996), support the idea of an anti-epileptic role. Furthermore, experiments on epilepsy models have provided conflicting, inconclusive results (Mathis et al., 1998; Gutierrez et al., 2001). In one study, an N/OFQ analog produced pro-epileptic effects, but these were blocked by naloxone (thus, they were not NOP mediated); in the other, intraventricularly injected N/OFQ retarded kindling development but did not attenuate kindled seizures. 
In an attempt to examine this controversial issue, we decided to investigate the adaptive changes taking place in the N/OFQ-NOP system during seizures and their functional pro-seizure or antiseizure consequences by using an integrated pharmacological and genetic approach. Thus, we first analyzed changes in proN/OFQ (the N/OFQ precursor) mRNA levels and in NOP mRNA levels and receptor binding after acute, kainate-evoked limbic seizures. Second, we evaluated expression of kainate seizures in mice treated with a NOP receptor antagonist, 1-[(3R, 4R)-1-cyclooctylmethyl-3-hydroxymethyl-4-piperidyl]-3-ethyl-1,3-dihydro-benzimidazol-2-one (J-113397) (Ozaki et al., 2000), and in mice made N/OFQ deficient by targeted disruption of the proN/OFQ gene (Köster et al., 1999).

\section{MATERIALS AND METHODS}

Animals. Adult male Sprague Dawley rats (300-350 gm; Harlan), male C57BL/6 mice (25 gm; Harlan), and N/OFQ knock-out mice have been used for the experiments. The knock-out animals used in this study were progeny of a hybrid C57BL/ $6 \times 129 /$ Ola mice. Details on the generation of these animals have been given previously (Köster et al., 1999). Experiments were performed using homozygous wild-type $(+/+)$ and homozygous mutant $(-/-)$ mice for the targeted proN/OFQ allele that were littermates born from heterozygous breeding pairs.

All animals were housed under standard conditions: constant temperature $\left(22-24^{\circ} \mathrm{C}\right)$ and humidity $(55-65 \%), 12 \mathrm{hr}$ dark/light cycle, ad libitum access to food and water. Adult N/OFQ knock-out mice have never been housed in large groups (more than three per cage) to avoid social stress (Köster et al., 1999). Procedures involving animals were conducted in accordance with European Community and national (Ministry of Health) laws and policies (authorizations: D.M. 69/98-B and 82/2001-B).

Kainate was administered intraperitoneally $(10 \mathrm{mg} / \mathrm{kg}$ in rats, 20 $\mathrm{mg} / \mathrm{kg}$ in mice). The rat behavior was observed for $6 \mathrm{hr}$ thereafter. Within the first hour after injection, $80 \%$ of the animals developed seizures evolving into recurrent generalized tonic-clonic convulsions (status epilepticus). These rats were killed at different times after kainate injection, and their brains were used for Northern blot analysis, in situ hybridization, or receptor binding assay, as described below. The remaining $20 \%$ of the animals either did not seize or died within the first $3 \mathrm{hr}$ and were not included in the study. Controls were vehicle injected or naive (real control) rats.

The mouse behavior was observed for $2 \mathrm{hr}$ after kainate administration. The occurrence of seizures and their severity were scored by investigators blind to the previous treatment, using the following classification (Janumpalli et al., 1998): 1, chewing and drooling; 2, head nodding; 3 , unilateral forelimb clonus; 4 , bilateral forelimb clonus; 5 , bilateral forelimb and/or hindlimb clonus with falling; 6, running or jumping seizure; 7, tonic hindlimb extension; 8, death. A subset of N/OFQ knock-out and wild-type mice has been used for electroencephalographic (EEG) recordings. Under halothane anesthesia, these mice were implanted with a recording electrode in the right parietal cortex (1 $\mathrm{mm}$ deep from dura) fixed to the skull with four stainless steel screws and methylacrylic cement. Mice were allowed $7 \mathrm{~d}$ to recover before the kainate experiment. Controls were vehicle-injected, naïve, or wild-type littermate mice. A group of C57BL/6 mice was killed $6 \mathrm{hr}$ after kainate injection, and their brains were used for Northern blot analysis, as described below.

Tissue processing. Rats and mice were killed at different times (rats at 3,6 , and $24 \mathrm{hr}$; mice at $6 \mathrm{hr}$ ) after kainate administration by decapitation under light diethyl-ether anesthesia, and their brains were removed rapidly. For Northern and binding assay, hippocampi and thalami were dissected and frozen. For in situ hybridization, brains were frozen in isopentane cooled in a dry ice-methanol bath and stored at $-70^{\circ} \mathrm{C}$ until use.

Total RNA for Northern analysis was prepared according to the method of Chomczynski and Sacchi (1987), as described previously (Romualdi et al., 1995). RNA was extracted by homogenizing single tissue samples in a mixture of guanidinium thiocyanate/phenol $(2 \mathrm{ml} / 100$ $\mathrm{mg}$ tissue), adding $0.2 \mathrm{ml}$ chloroform $/ 2 \mathrm{ml}$ of homogenate, and centrifuging the suspension at $12,000 \times g$ for $25 \mathrm{~min}$ at $4^{\circ} \mathrm{C}$. The aqueous phase was then transferred to a fresh tube, an equal volume of isopropanol was added, and it was incubated for $15 \mathrm{~min}$ at $4^{\circ} \mathrm{C}$; the RNA pellet was isolated by centrifugation at $12,000 \times g$ for $25 \mathrm{~min}$ at $4^{\circ} \mathrm{C}$. Finally, the pellet was washed twice with $75 \%$ ethanol, dried under vacuum, and resuspended in $0.5 \%$ SDS. Total RNA content was quantified by measurement of absorbance at $260 \mathrm{~nm}$, and an $\mathrm{OD}_{260} / \mathrm{OD}_{280}$ ratio $>1.8$ provided an estimate of the purity of the total RNA.

Probes. All probes were prepared from a full-length cDNA insert cloned in a pBluescript $\mathrm{SK}(+)$ plasmid (proN/OFQ from C. Mollereau, Centre National de la Recherche Scientifique, Toulouse, France; NOP from O. Civelli, Department of Pharmacology, University of California at Irvine, CA). For Northern blot analysis, the proN/OFQ probe consisted of the EcoRI-digested fragments, and the NOP probe consisted of the NotI, HindIII-digested fragments of the plasmids. The cDNA fragments were labeled by the random priming method using $\alpha\left[{ }^{32} \mathrm{P}\right]$-dCTP to a specific activity of $7-9 \times 10^{5} \mathrm{cpm} / \mathrm{ng}$. A cDNA fragment recognizing $\beta$-actin mRNA (clone pHF $\beta A-1$, containing the full-length cDNA insert for human cytoplasmatic $\beta$-actin) was used as internal standard to hybridize the same blots (Gunning et al., 1983).

For in situ hybridization, the proN/OFQ plasmid was linearized with Bam H1 and transcribed with T7 RNA polymerase to obtain antisense riboprobes or linearized with $\mathrm{XhoI}$ and transcribed with T3 RNA polymerase to obtain sense riboprobes. The NOP plasmid was linearized with NdeI and transcribed with T3 RNA polymerase to obtain antisense riboprobes or with T7 RNA polymerase to obtain sense riboprobes. All riboprobes were obtained by running the respective transcription assays in the presence of $\alpha\left[{ }^{33} \mathrm{P}\right]-$ rUTP and hydrolyzed to fragments of $\sim 200$ base pairs with sodium carbonate at $60^{\circ} \mathrm{C}$.

Northern blot analysis. Total RNA from each tissue $(30 \mu \mathrm{g})$ was electrophoresed, transferred by overnight capillary blotting to nylon membranes, and then air dried, and UV cross-linked. After prehybridization for $4 \mathrm{hr}$, blots were hybridized for $24 \mathrm{hr}$ at $42^{\circ} \mathrm{C}$ in $5 \times \mathrm{SSPE}$ (saline-sodium phosphate-EDTA; $1 \times \mathrm{SSPE}=150 \mathrm{~mm} \mathrm{NaCl}, 10 \mathrm{~mm}$ $\mathrm{NaH}_{2} \mathrm{PO}_{4}, 1 \mathrm{~mm}$ EDTA), $5 \times$ Denhardt's solution $(1 \times$ Denhardt's solution $=0.02$ polyvinylpyrrolidone, $0.2 \%$ Ficoll, $0.02 \%$ BSA), $250 \mu \mathrm{g} / \mathrm{ml}$ denatured salmon sperm DNA, $0.3 \%$ SDS, $50 \%$ formamide, and $10 \%$ dextran sulfate, containing the probe at the concentration of $2 \times 10^{6}$ $\mathrm{cpm} / \mathrm{ml}$. Blots were washed three times for $10 \mathrm{~min}$ at $42^{\circ} \mathrm{C}$ with $2 \times \mathrm{SSC}$ (saline-sodium citrate) $(1 \times \mathrm{SSC}=150 \mathrm{~mm} \mathrm{NaCl}, 15 \mathrm{~mm}$ sodium citrate) $/ 0.1 \%$ SDS and then three times for $10 \mathrm{~min}$ at $55^{\circ} \mathrm{C}$ with $0.1 \times$ SSC $/ 0.1 \%$ SDS. X-ray films (Amersham $\beta$-max) were exposed to the hybridized blot at $-70^{\circ} \mathrm{C}$ for $21 \mathrm{~d}$. Blots were hybridized serially twice with probes directed against proN/OFQ (or NOP) and $\beta$-actin mRNA. $\beta$-actin mRNA hybridization was run as described previously (Romualdi et al., 1995).

Optical densities for autoradiographic bands were determined using a Video Densitometer system (MDL 620). Multiple exposures to film and the presence of standardizing lanes prevented saturation of the x-ray film. Background densities from areas of film away from the lanes were subtracted from the observed values, which were obtained from nonsaturated autoradiographic exposures in which standardizing lanes revealed a linear relationship between amount of mRNA and hybridization signal. Two autoradiograms for each blot were scanned. The proN/OFQ $/ \beta$-actin or the $\mathrm{NOP} / \beta$-actin mRNA ratios of hybridization values for treated or control animals were analyzed and then expressed as percentages of controls.

In situ hybridization. Coronal sections $(20 \mu \mathrm{m})$ at the level of the ventral hippocampus [plate 39 (Pellegrino et al., 1979)] were thaw mounted onto poly-lysine-coated slides, fixed in paraformaldehyde $4 \%$, soaked in $3 \times$ PBS, rinsed in a graded ethanol series, dried, and then stored at $-20^{\circ} \mathrm{C}$ until use. Immediately before in situ hybridization, they were pretreated with proteinase $\mathrm{K}\left(1 \mu \mathrm{g} / \mu \mathrm{l}, 10 \mathrm{~min}, 37^{\circ} \mathrm{C}\right)$ and acetic anhydride $(0.25 \% \mathrm{v} / \mathrm{v}, 10 \mathrm{~min}$, room temperature).

In situ hybridization was performed as described previously (Simonato et al., 1996). The in situ hybridization mixture contained 50\% deionized formamide, $2 \times$ STE (sodium-Tris-EDTA), $5 \times$ Denhardt's solution, 100 $\mu \mathrm{g} / \mathrm{ml}$ salmon sperm DNA, $100 \mu \mathrm{g} / \mathrm{ml}$ transfer RNA, $0.05 \%$ sodium pyrophosphate, and $60 \mathrm{ng} / \mathrm{ml}\left[{ }^{33} \mathrm{P}\right]$-riboprobe. Sections were incubated overnight at $52^{\circ} \mathrm{C}$ with $40 \mu \mathrm{l}$ hybridization mixture. They were then rinsed twice for $10 \mathrm{~min}$ in $4 \times \mathrm{SSC}$, treated with RNase A $(20 \mu \mathrm{g} / \mathrm{ml}, 30$ $\min , 37^{\circ} \mathrm{C}$ ), then washed in $1 \times \mathrm{SSC}$ for $10 \mathrm{~min}, 0.1 \times \mathrm{SSC}$ at $52^{\circ} \mathrm{C}$ for 30 min, $0.1 \times$ SSC at room temperature for $10 \mathrm{~min}$, and dehydrated. Autoradiograms were generated by apposing these dried sections alongside $\left[{ }^{33} \mathrm{P}\right]$-riboprobe standards to Amersham Hyperfilm $\beta$-max at $-70^{\circ} \mathrm{C}$ for $30 \mathrm{~d}$.

The mean total optical density within an area of interest was calculated by multiple sampling of that area in four sections taken from each animal using a digital analysis system (RBR Altair, Firenze, Italy). Background 
(nonspecific) hybridization was estimated using other sections incubated with the sense probe and subtracted from the total optical density. These specific optical density measurements were then compared with those obtained from the $\left[{ }^{33} \mathrm{P}\right]$-riboprobe standards to convert $\mathrm{OD}$ units into units of moles per millimeters squared, as described previously (Hosford et al., 1995). This method of standardization allows comparison of values obtained from homologous regions across different films. Finally, data have been expressed as percentage of control (sham-stimulated and control rats).

Binding. Tissue samples were homogenized in $40 \mathrm{vol}$ of buffer [Tris$\mathrm{HCl} 50 \mathrm{~mm}, \mathrm{pH}$ 7.4, EDTA $2 \mathrm{~mm}$, phenylmethylsulfonyl fluoride (PMSF) $100 \mathrm{mM}$, sucrose $0.3 \mathrm{M}$ ] in a glass Dounce homogenizer. Homogenates were centrifuged at $1000 \times g$ for $10 \mathrm{~min}$ at $4^{\circ} \mathrm{C}$. The supernatants were centrifuged at $35,000 \times g$ for $10 \mathrm{~min}$, and the pellets were resuspended in $50 \mathrm{vol}$ of sucrose-free buffer, incubated for $30 \mathrm{~min}$ at room temperature, and then centrifuged again at $35,000 \times g$ for $10 \mathrm{~min}$. The final pellets were resuspended in $50 \mathrm{vol}$ of sucrose-free buffer. Aliquots of these suspensions were removed for protein concentration determination using the method of Lowry et al. (1951). Bovine serum albumin (BSA; 2 $\mathrm{mg} / \mathrm{ml}$ ) was added to the final suspension, which was immediately used for the binding assay.

The binding assay was performed in Tris- $\mathrm{HCl}$ buffer (Tris- $\mathrm{HCl} 50 \mathrm{~mm}$, pH 7.4, EDTA 2 mu, PMSF $100 \mathrm{~mm}, 0.1 \%$ BSA) in a final volume of 0.25 $\mathrm{ml}$ containing $70-100 \mu \mathrm{g}$ of protein. Competition experiments were performed in the presence of $1 \mathrm{~nm}$ [leucyl- $\left.{ }^{3} \mathrm{H}\right]-\mathrm{N} / \mathrm{OFQ}$ (specific activity $165 \mathrm{Ci} / \mathrm{mmol}$; Amersham Biosciences). Competition curves were obtained using unlabeled N/OFQ (Bachem) at nine different concentrations, ranging between 0.010 and 10,000 nM. Assay tubes were incubated at $25^{\circ} \mathrm{C}$ for $1 \mathrm{hr}$. Saturation curves were obtained by incubating [leucyl$\left.{ }^{3} \mathrm{H}\right]-\mathrm{N} / \mathrm{OFQ}$ at eight different concentrations (0.05-12 nM) in a final volume of $0.25 \mathrm{ml}$ for $1 \mathrm{hr}$. Nonspecific binding was determined in the presence of $5 \mu \mathrm{M}$ N/OFQ. The reaction was terminated by vacuum filtration through GF-B filters previously soaked in $0.3 \%$ polyethylenimine for $3 \mathrm{hr}$ to reduce nonspecific binding. Filters were washed three times with $4 \mathrm{ml}$ of assay buffer at $4^{\circ} \mathrm{C}$. Filter-bound radioactivity was counted in $4 \mathrm{ml}$ of scintillation fluid (Filter Count, Packard) using a Beckman LS1701 counter. Saturation assays were run in quadruplicate. Curves were analyzed to obtain $B_{\max }$ and $K_{\mathrm{D}}$ values using the GraphPad Prism 3.02 software.

Drug treatments. J-113397 was a racemic mixture synthesized (De Risi et al., 2001) and kindly provided by G. P. Pollini and C. De Risi (Department of Medicinal Chemistry, University of Ferrara, Ferrara, Italy). It was injected intracerebroventricularly $(10 \mathrm{nmol}$ in $2 \mu \mathrm{l})$. At this dose and route of administration, racemic J-113397 was fully effective in preventing N/OFQ-induced hyperalgesia (A. Rizzi, personal communication). For rescue experiments in N/OFQ knock-out mice, N/OFQ was administered at a dose $(3 \mathrm{nmol}$, i.c.v. $)$ reported to be effective in producing hyperalgesia and anti-analgesia (Grisel and Mogil, 2000). N/OFQ was kindly provided by S. Salvadori and R. Guerrini (Department of Medicinal Chemistry, University of Ferrara, Ferrara, Italy).

Intracerebroventricular injections were given in the left ventricle, according to the procedure described by Laursen and Belknap (1986). After skull exposure, the bregma was identified by lightly rubbing the needle tip on the skull. The needle was inserted $\sim 2 \mathrm{~mm}$ lateral from the midline, holding the syringe at an $\sim 45^{\circ}$ angle to the skull. Because the skull is relatively thin at this position, mild pressure was sufficient to insert the needle. The drug solution was injected slowly $(2 \mu \mathrm{l}$ in $20 \mathrm{sec})$, and kainate was administered 2-3 min thereafter. Control mice were administered saline $(2 \mu$ l, i.c.v., in $20 \mathrm{sec})$.

\section{RESULTS}

\section{Kainate seizures differentially affect proN/OFQ and NOP gene expression}

Northern blot analysis allowed detection of proN/OFQ mRNA with a $1.35 \mathrm{~kb}$ size in the rat hippocampus and cortex. No differences were detected in vehicle-injected rats compared with untreated controls, and thus these two groups were pooled together for statistical analysis and termed collectively control. In keeping with previous reports (Bregola et al., 1999), proN/OFQ mRNA levels were increased in the thalamus, but not in the hippocampus, 3-24 hr after kainate administration (Fig. 1), with

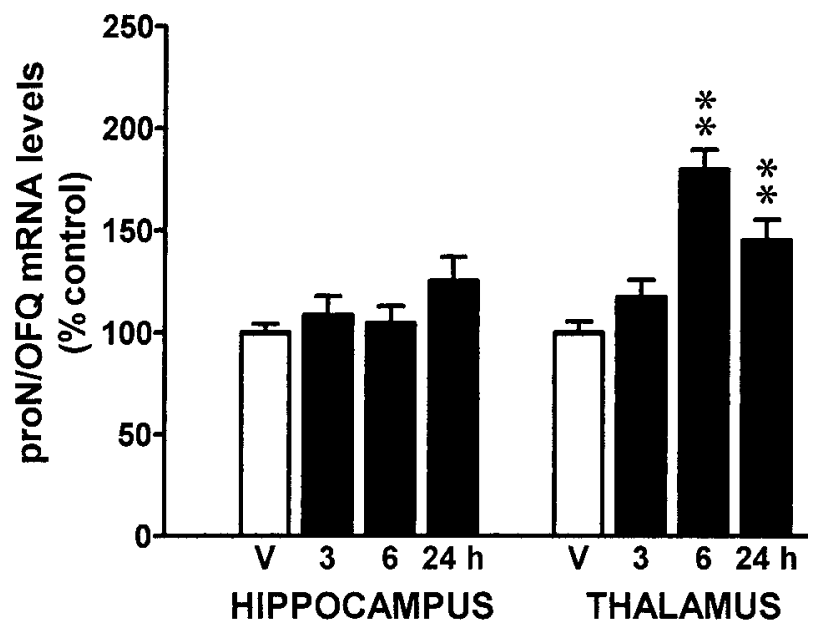

Figure 1. Time course of the effect of kainate-induced status epilepticus on proN/OFQ mRNA levels in the rat hippocampus and thalamus. Shown are the optical density values for autoradiographic bands produced by proN/OFQ hybridization, expressed as percentage of control (mean mRNA levels in vehicle-injected rats $=100 \%)$. Data are the mean $\pm \mathrm{SE}$ of four to five independent experiments (i.e., of 4-5 animals per group). $V$, Vehicle injected; 3, 6, $24 \mathrm{~h}$, rats killed 3, 6, or $24 \mathrm{hr}$ after kainate injection. $* * p<0.01$ versus vehicle; ANOVA and post hoc NewmanKeuls test.

maximal effect (twofold increase over basal levels) reached $6 \mathrm{hr}$ after injection.

Northern blot analysis also allowed detection of NOP mRNA in the rat brain. As reported previously (Xie et al., 1999), NOP was found in three bands with sizes of $\sim 3.4,8-9$, and $10-12 \mathrm{~kb}$ (Fig. 2), indicative of the existence of splice variants. In contrast with proN/OFQ, the NOP gene expression was found to decrease dramatically in both the thalamus and hippocampus after kainate administration (Fig. 3). This phenomenon was more profound in the thalamus, where it reached a maximum (approximately $-70 \%$ ) $6 \mathrm{hr}$ after kainate. Interestingly, all three bands underwent identical changes in time, indicating identical variations of the respective mRNA levels. No differences in $\beta$-actin mRNA levels were found between the different experimental groups in any of the tissues examined.

In situ hybridization analysis confirmed and extended these findings. As described previously (Bregola et al., 1999; Neal et al., 1999a), in coronal sections taken from control rats at the level of the dorsal hippocampus, relatively high constitutive proN/OFQ gene expression was found in the reticular nucleus of the thalamus, in the medial nucleus of the amygdala, and at lower levels in the dentate gyrus of the hippocampus (Fig. 4). In adjacent sections (Fig. 4), relatively high constitutive NOP receptor gene expression was found in the cortex (neocortex and entorhinal and piriform cortex), in the hippocampal formation (mainly dentate gyrus and CA3), in the amygdala (mainly medial and basal nucleus), and in various nuclei of the thalamus and hypothalamus (Neal et al., 1999b). No differences were detected between control and vehicle-injected rats for both genes, and these two groups were pooled together for statistical analysis and termed collectively control.

Variations in the pattern of proN/OFQ and NOP gene expression have been studied by comparing control and vehicle-injected rats with kainate-treated rats killed 6 hr after kainate administration (maximal proN/OFQ mRNA level increase and maximal NOP mRNA level decrease, on the basis of the above-described 


\section{HIPPOCAMPUS}

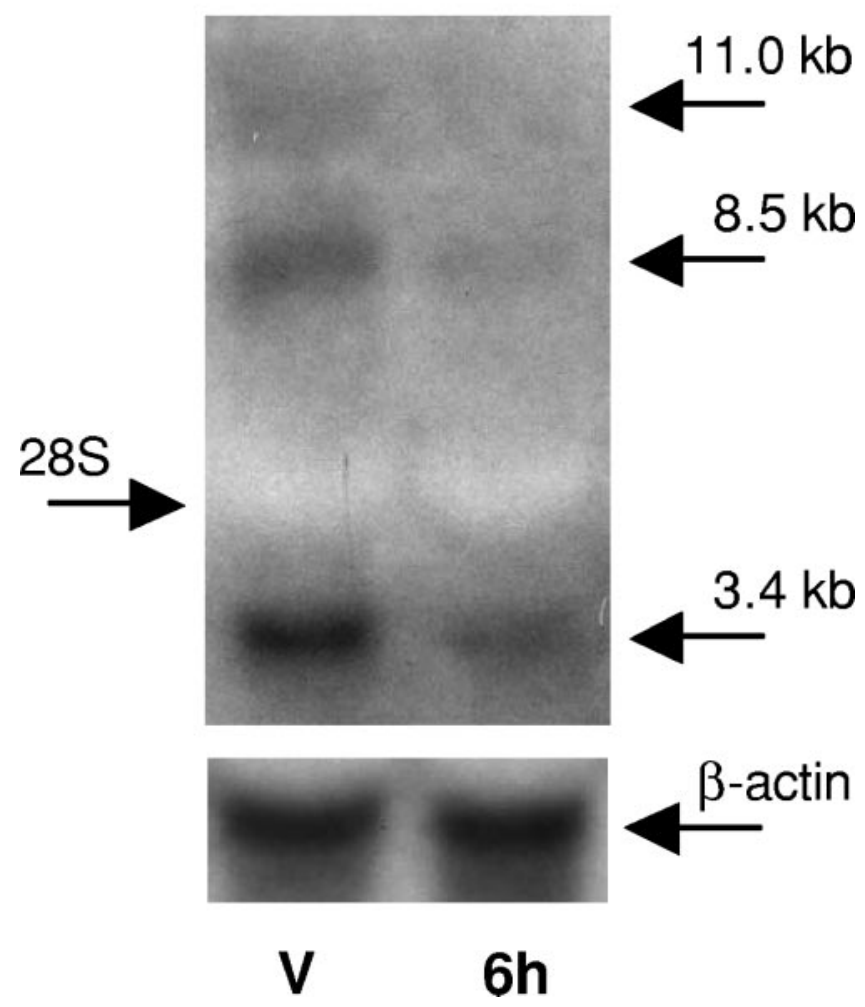

Figure 2. Northern blot analysis of the effect of kainate administration on NOP and $\beta$-actin mRNA levels in the rat hippocampus. A representative autoradiogram is shown. Total RNA was extracted from the hippocampus, electrophoresed on agarose gel, transferred to nylon membranes, and allowed to hybridize with radiolabeled probes for NOP and $\beta$-actin. Note the three bands for NOP mRNA that are 10-12, 8-9, and $3.4 \mathrm{~kb}$ in size. Shown on the left is the position corresponding to $28 \mathrm{~S}$ rRNA $(5.1 \mathrm{~kb}) . V$, Vehicle injected; $6 h$, rats killed $6 \mathrm{hr}$ after kainate injection.

Northern blot analysis). ProN/OFQ mRNA levels increased 2.7fold in the thalamic reticular nucleus and 1.6-fold in the medial nucleus of the amygdala after kainate injection (Fig. 4, Table 1); a smaller, not significant increase was observed over the dentate gyrus of the hippocampus as compared with control animals (Table 1). In contrast, NOP mRNA levels decreased in a profound $(-50 \%)$ and widespread manner after kainate injection, e.g., in the amygdala, hippocampus, thalamus, and cortex (Fig. 4, Table 1).

To verify whether decreased NOP gene expression actually leads to receptor downregulation, radioligand binding studies have been performed at later time-points after kainate administration compared with those used for gene expression analysis. First, displacement experiments have been conducted to monitor the changes in receptor density. Indeed, kainate-induced seizures were found to cause a progressive decrease of receptor density after kainate administration [hippocampus (femtomoles per milligram of protein): control, $243 \pm$ 9, 1 d after kainate, $205 \pm 2$, 3 d after kainate, $161 \pm 10$; thalamus (femtomoles per milligram of protein): control, $235 \pm 11,1 \mathrm{~d}, 215 \pm 5,3 \mathrm{~d}, 181 \pm 2$; means $\pm \mathrm{SE}$ of six animals per group; $p<0.05$ for the $3 \mathrm{~d}$ compared with controls for both hippocampus and thalamus (ANOVA and post hoc NewmanKeuls test)]. This phenomenon was also observed in the cortex of

\section{HIPPOCAMPUS}

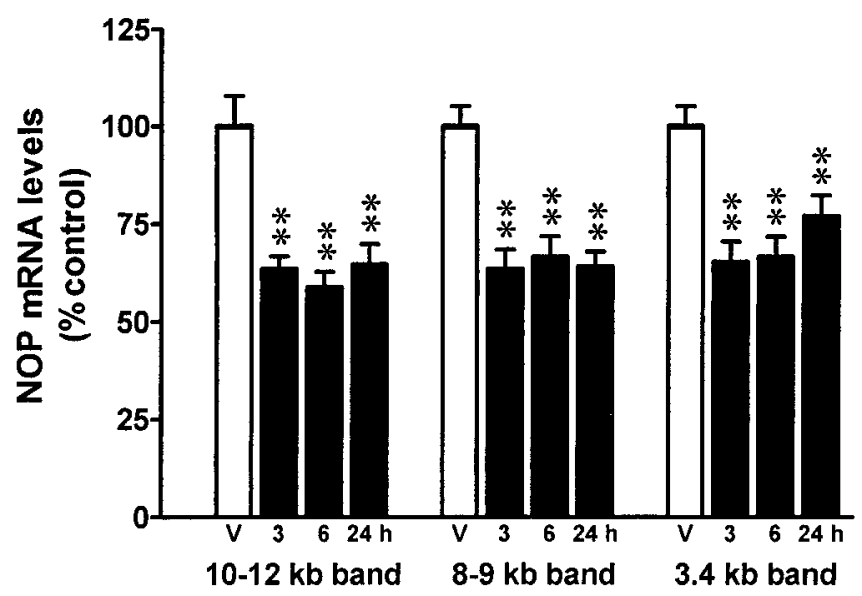

THALAMUS

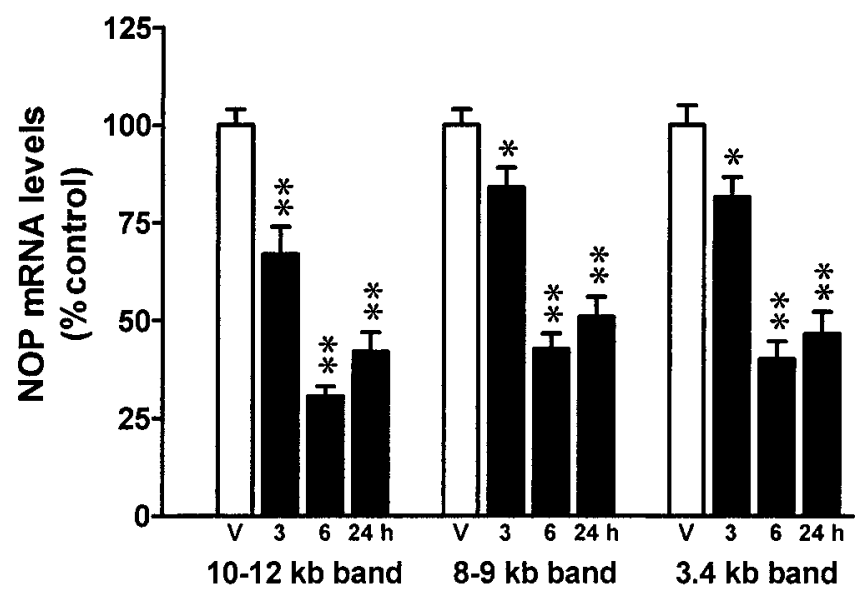

Figure 3. Time course of the effect of kainate-induced status epilepticus on NOP mRNA levels in the rat hippocampus and thalamus. Shown are the optical density values for autoradiographic bands produced by NOP hybridization, expressed as percentage of control (mean mRNA levels in vehicle-injected rats $=100 \%$ ). Data are the mean \pm SE of four to five independent experiments (i.e., of 4-5 animals per group). $V$, Vehicleinjected; 3, 6, $24 h$, rats killed 3, 6, or $24 \mathrm{hr}$ after kainate injection. ${ }^{* *} p<$ 0.01 versus vehicle; ANOVA and post hoc Newman-Keuls test.

treated rats (data not shown). Second, saturation experiments have been performed to accurately quantify the changes in receptor binding. Three days after kainate seizures, NOP receptor density was highly decreased in the rat hippocampus and thalamus, as indicated by a significant reduction in the $B_{\max }$ values (Fig. 5, Table 2). No significant changes were observed in affinity (Table 2).

Finally, to verify that the adaptive changes in the N/OFQ-NOP system observed in the rat also occur in the mouse, a group of mice were killed $6 \mathrm{hr}$ after kainate injection, and their brains were used for Northern blot analysis of NOP mRNA expression in the hippocampus and thalamus. NOP mRNA in the mouse was found in three bands of approximately the same size observed in the rat (see above), but a prominent expression of the $3.4 \mathrm{~kb}$ band was observed. In keeping with the findings in the rat, NOP expression decreased dramatically in both the thalamus and hippocampus 6 hr after kainate administration (Fig. 6). 


\section{CONTROL}
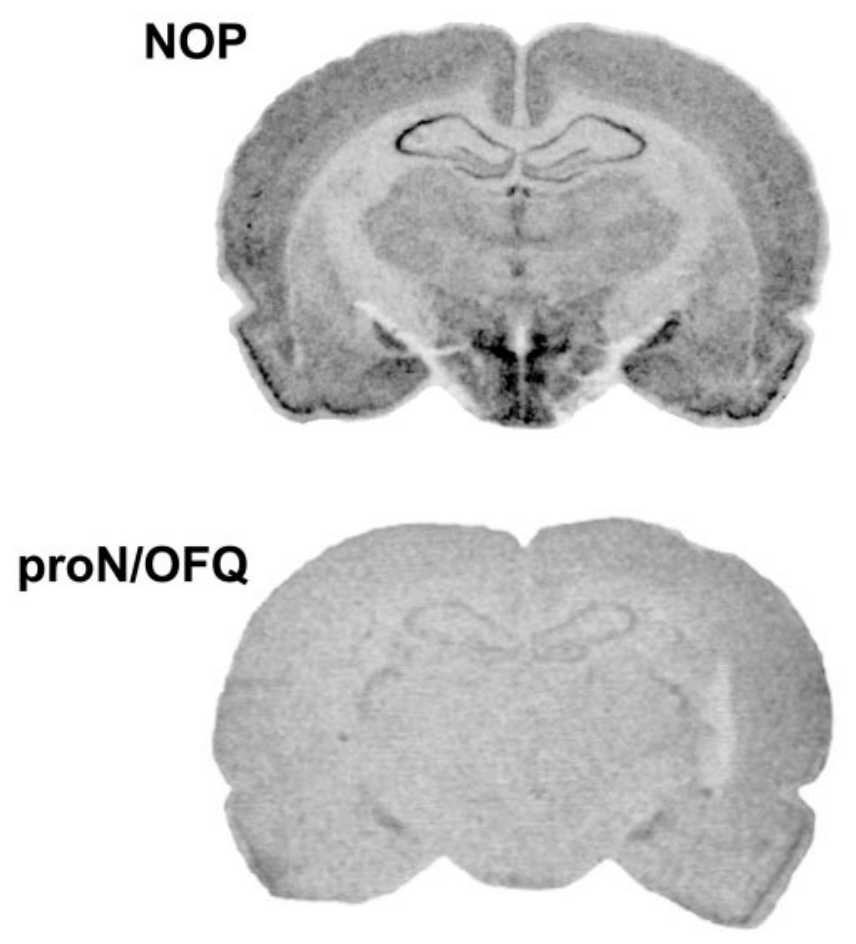

KAINATE
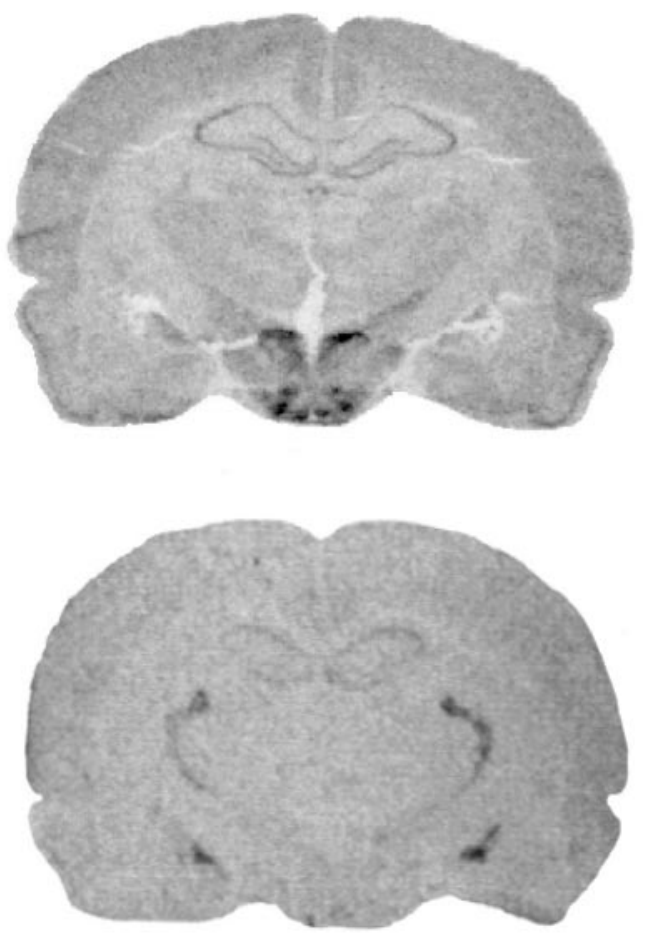

Figure 4. Anatomical distribution of proN/OFQ and NOP mRNA expression in control rats and in kainate-treated rats, killed 6 hr after intraperitoneal injection of the drug. Shown are autoradiograms of representative coronal brain sections at the level of the dorsal hippocampus [plate 39 (Pellegrino et al., 1979)], exhibiting total hybridization of the $\left[{ }^{33} \mathrm{P}\right]$-labeled probes. These representative sections will not correlate fully with the mean changes in proN/OFQ and NOP mRNA levels shown in Table 1 because of slight differences in gene expression in the four to six animals of each group.

\section{Assessment of the involvement of the N/OFQ system in kainate seizures}

To examine the involvement of the N/OFQ system in kainate seizure expression, we used two distinct approaches. In the first, a pharmacological approach, we examined the effect of an NOP receptor antagonist, J-113397 (Kawamoto et al., 1999; Ozaki et al., 2000) on kainate seizure expression in C57BL/6 mice; in the second, a genetic approach, we assessed kainate seizure susceptibility in N/OFQ knock-out mice (Köster et al., 1999).

The NOP receptor antagonist J-113397 (10 nmol, i.c.v.) was devoid of any primary effect on the gross behavior of the mice. However, this dose fully prevented N/OFQ-induced hyperalgesia (see Materials and Methods). J-113397 decreased susceptibility to seizures induced by kainate $(20 \mathrm{mg} / \mathrm{kg}$, i.p.): seizure scores were significantly reduced (Fig. 7). Furthermore, lethality was decreased (11\% in the saline group, $0 \%$ in the $\mathrm{J}-113397$ group) and latency to generalized (first severe, class 4 or higher) seizure onset was delayed slightly ( $42 \pm 2 \mathrm{~min}$ in the saline group, $48 \pm$ 4 min in the J-113397 group), but both in a nonsignificant manner.

Homozygous N/OFQ $-/-$ and N/OFQ +/+ littermate mice were also injected with kainate $(20 \mathrm{mg} / \mathrm{kg}$, i.p.), and their behavior and EEG were recorded for $2 \mathrm{hr}$ thereafter. N/OFQ knock-out mice displayed reduced susceptibility to kainate-induced seizures: (1) lethality was reduced ( 9 vs $36 \%$ in their wild-type littermates); (2) latency to generalized seizure onset was delayed (40 \pm 5 vs $22 \pm 4$ min in the wild-type; $p<0.01$; Student's $t$ test for unpaired data); and (3) behavioral seizure scores were reduced significantly (Fig. 7). However, in the $2 \mathrm{hr}$ after kainate administration, EEG seizure duration was not significantly different in the two groups (1238 $\pm 346 \mathrm{sec}$ in wild-type vs $1586 \pm 562 \mathrm{sec}$ in knock-out mice). To determine whether the differences in seizure susceptibility were caused by the absence of N/OFQ, the peptide was injected intracerebroventricularly ( $3 \mathrm{nmol}$ in $2 \mu \mathrm{l}$ ) 2-3 min before kainate administration in N/OFQ knock-out mice. A group of N/OFQ knock-out mice was treated with an equal volume of saline intracerebroventricularly. Under these experimental conditions, N/OFQ did not alter the gross behavior of the mice, but it rescued the normal phenotype: lethality and behavioral seizure scores increased (lethality to $33 \%$; seizure index to $3.5 \pm 0.5$; cumulative score to $75 \pm$ 6 ), and the latency to generalized seizures shortened (32 $\pm 6 \mathrm{~min})$. All of these parameters were not significantly different from those observed in wild-type littermate mice, and all except latency were significantly different from those observed in untreated and salineinjected N/OFQ knock-out mice.

\section{DISCUSSION}

Two main findings emerge from this study. First, the N/OFQNOP system undergoes adaptive changes after kainate seizures. In particular, N/OFQ biosynthesis increases and NOP receptors downregulate. Second, pharmacological and genetic interruption of the N/OFQ signal produces anticonvulsant effects. This indicates that N/OFQ may participate in seizure generation or amplification and, thus, that the NOP receptor may represent a new therapeutic target for some forms of epilepsy. These findings will be discussed separately below. 
Table 1. Changes in proN/OFQ and NOP gene expression in rat forebrain regions $6 \mathrm{hr}$ after systemic administration of kainate $(10 \mathrm{mg} / \mathrm{kg})$

\begin{tabular}{|c|c|c|c|c|}
\hline & \multicolumn{2}{|l|}{ Control $^{a}$} & \multicolumn{2}{|l|}{ Kainate $^{a}$} \\
\hline & Right & Left & Right & Left \\
\hline \multicolumn{5}{|l|}{ proN/OFQ } \\
\hline \multicolumn{5}{|l|}{ Amygdala } \\
\hline Medial nucleus & $100 \pm 17$ & $98 \pm 20$ & $167 \pm 22^{*}$ & $157 \pm 16^{*}$ \\
\hline \multicolumn{5}{|l|}{ Hippocampus } \\
\hline Dentate gyrus & $43 \pm 7$ & $52 \pm 7$ & $69 \pm 9$ & $69 \pm 9$ \\
\hline \multicolumn{5}{|l|}{ Thalamus } \\
\hline Reticular nucleus & $58 \pm 12$ & $57 \pm 13$ & $158 \pm 19^{* *}$ & $156 \pm 22^{* *}$ \\
\hline \multicolumn{5}{|l|}{ NOP } \\
\hline $\begin{array}{l}\text { Piriform cortex } \\
\text { Amygdala }\end{array}$ & $100 \pm 5$ & $101 \pm 15$ & $49 \pm 4^{* *}$ & $56 \pm 5^{*}$ \\
\hline Medial nucleus & $87 \pm 8$ & $92 \pm 7$ & $45 \pm 5^{* *}$ & $40 \pm 3^{* *}$ \\
\hline \multicolumn{5}{|l|}{ Thalamus } \\
\hline Ventral nucleus & $46 \pm 2$ & $42 \pm 4$ & $30 \pm 1 * *$ & $26 \pm 3^{*}$ \\
\hline \multicolumn{5}{|l|}{ Hippocampus } \\
\hline Dentate gyrus & $54 \pm 4$ & $53 \pm 7$ & $37 \pm 3^{*}$ & $36 \pm 5^{*}$ \\
\hline CA3 & $90 \pm 5$ & $85 \pm 15$ & $45 \pm 4^{* *}$ & $42 \pm 4^{*}$ \\
\hline CA1 & $55 \pm 7$ & $48 \pm 10$ & $33 \pm 4$ & $32 \pm 3$ \\
\hline \multicolumn{5}{|l|}{ Neocortex } \\
\hline Layer IV & $54 \pm 4$ & $54 \pm 5$ & $32 \pm 1^{* *}$ & $27 \pm 3^{* *}$ \\
\hline
\end{tabular}

$\bar{*} p<0.05,{ }^{*} p<0.01$ versus the corresponding region in controls; ANOVA and post hoc Newman-Keuls test.

${ }^{a}$ Optical density values have been calculated as described in Materials and Methods and are expressed as percentage of the specific optical density over the right medial nucleus of the amygdala of controls (for proN/OFQ) or over the right piriform cortex of controls (for NOP). Data are the mean \pm SE of four to six animals per group, each run in quadruplicate.
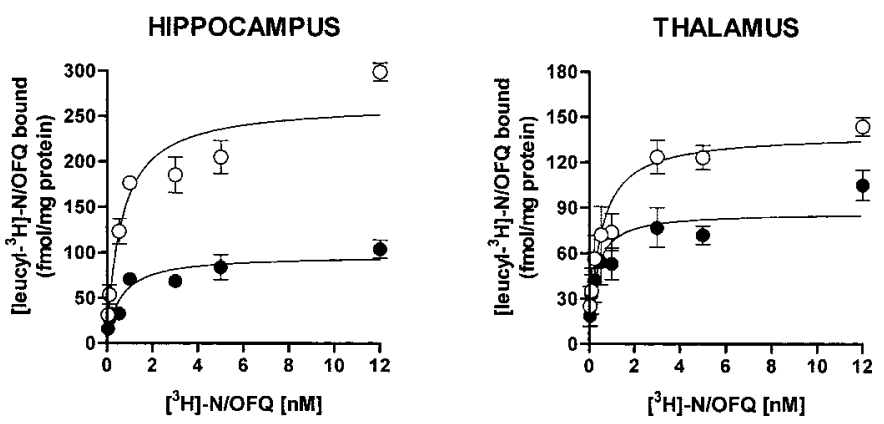

Figure 5. Saturation curves (specific binding) of $\left[\right.$ leucyl- $\left.{ }^{3} \mathrm{H}\right]-\mathrm{N} / \mathrm{OFQ}$ to NOP receptors in membranes prepared from hippocampi (left panel) and thalami (right panel) taken from control $(\bigcirc)$ and kainate-treated $(\bullet)$ rats. Kainate-treated animals were killed $3 \mathrm{~d}$ after administration of the convulsant agent. Data are the mean \pm SE of six rats per group.

\section{Adaptations of the N/OFQ-NOP system after seizures}

Increased proN/OFQ mRNA levels and decreased NOP mRNA levels and receptor density observed after kainate may depend on $\mathrm{N} / \mathrm{OFQ}$ release. The release mechanism of N/OFQ has not been studied in detail. However, in analogy with other neuropeptides (Hokfelt, 1991), it is most likely frequency dependent, i.e., requires bursting or high-frequency activity (events characteristic of seizures). In keeping with this idea, seizure-induced repetitive firing in the hippocampus causes release of another opioid peptide, dynorphin, with activation of prodynorphin gene expression (Simonato and Romualdi, 1996; Rocha et al., 1997). As for prodynorphin, the increase in proN/OFQ mRNA levels occurs
Table 2. $B_{\max }$ (fmol/mg protein) and $K_{\mathrm{D}}(\mathrm{nM})$ values of [leucyl- $\left.{ }^{3} \mathrm{H}\right]-\mathrm{N} /$ OFQ binding to NOP receptors in membranes prepared from hippocampi and thalami taken from control and kainate-treated rats

\begin{tabular}{lccccc} 
& \multicolumn{2}{c}{ Hippocampus } & & \multicolumn{2}{l}{ Thalamus } \\
\cline { 2 - 3 } \cline { 5 - 6 } \cline { 5 - 6 } & \multicolumn{1}{c}{$B_{\max }$} & $K_{\mathrm{D}}$ & & $B_{\max }$ & $K_{\mathrm{D}}$ \\
\hline Control $^{264.6 \pm 26.7}$ & $0.61 \pm 0.26$ & & $139.0 \pm 9.6$ & $0.47 \pm 0.13$ \\
Kainate $^{a}$ & $97.2 \pm 9.3^{* *}$ & $0.57 \pm 0.21$ & & $91.2 \pm 9.2^{*}$ & $0.34 \pm 0.14$
\end{tabular}

${ }^{*} p<0.05,{ }^{*} p<0.01$ versus the corresponding region in controls; two-tailed $t$ test. ${ }^{a}$ Kainate-treated animals were killed $3 \mathrm{~d}$ after administration of the convulsant agent. Data are the mean $\pm \mathrm{SE}$ of four to six animals per group, each run in quadruplicate.

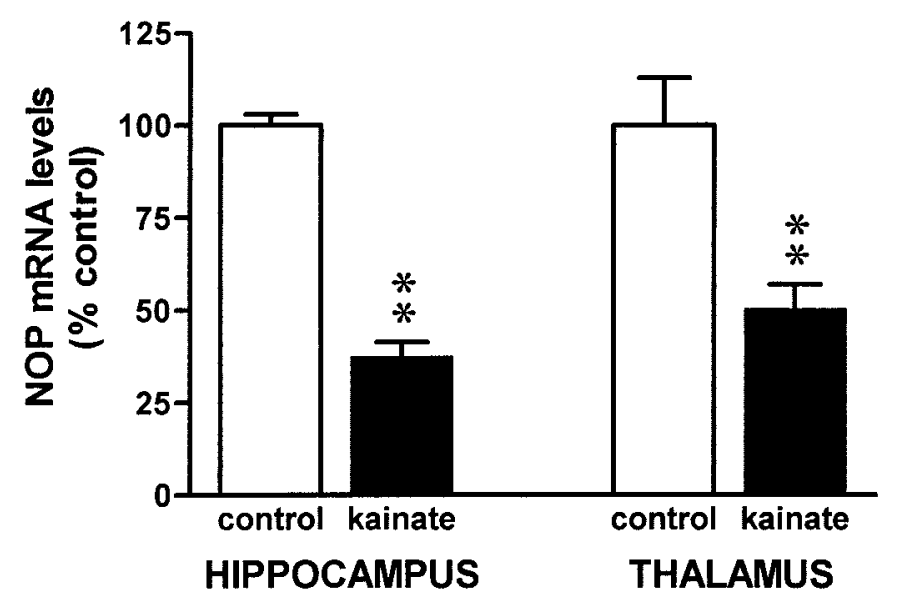

Figure 6. Effect of kainate-induced status epilepticus on NOP mRNA levels in the mouse hippocampus and thalamus. Shown are the optical density values for the $3.4 \mathrm{~kb}$ autoradiographic band produced by NOP hybridization, expressed as percentage of control (mean mRNA levels in vehicle-injected rats $=100 \%$ ). Percentage changes in the other two autoradiographic bands were identical to those reported in this figure for the 3.4 band. Data are the mean $\pm \mathrm{SE}$ of eight independent experiments (i.e., of 8 animals per group). Kainate-treated animals were killed $6 \mathrm{hr}$ after administration of the convulsant agent. ${ }^{*} p<0.01$ versus control; two-tailed $t$ test.

only within neuronal populations that constitutively express the gene, suggesting that seizures may indeed cause N/OFQ release, reducing its levels and stimulating new synthesis within the releasing neurons themselves. In line with this idea, small, nonsignificant increases in proN/OFQ mRNA levels have been observed after kindled seizures (Bregola et al., 1999) that are far less prolonged than those induced by kainate.

In turn, released N/OFQ may cause downregulation of NOP. Consistent with other reports (Chen et al., 1994; Wang et al., 1994; Lachowicz et al., 1995; Pan et al., 1995), we detected three bands for NOP mRNA in Northern analysis. It is thought that, as for other members of the opioid receptor family (Wick et al., 1995), the autoradiographic bands produced by NOP hybridization result from alternative splicing. Varying ratios of the larger bands to the $3.4 \mathrm{~kb}$ band, observed in different regions, suggest that NOP mRNA undergoes differential processing (Wang et al., 1994; Lachowicz et al., 1995). However, the observation of similar changes in time for the three bands suggests that, under our experimental conditions, regulation occurs at the gene promoter and not the RNA processing level.

In chronological agreement with mRNA level reduction, NOP receptor density in the hippocampus and thalamus progressively decreased in the $3 \mathrm{~d}$ after kainate administration. This observa- 


\section{J-113397}

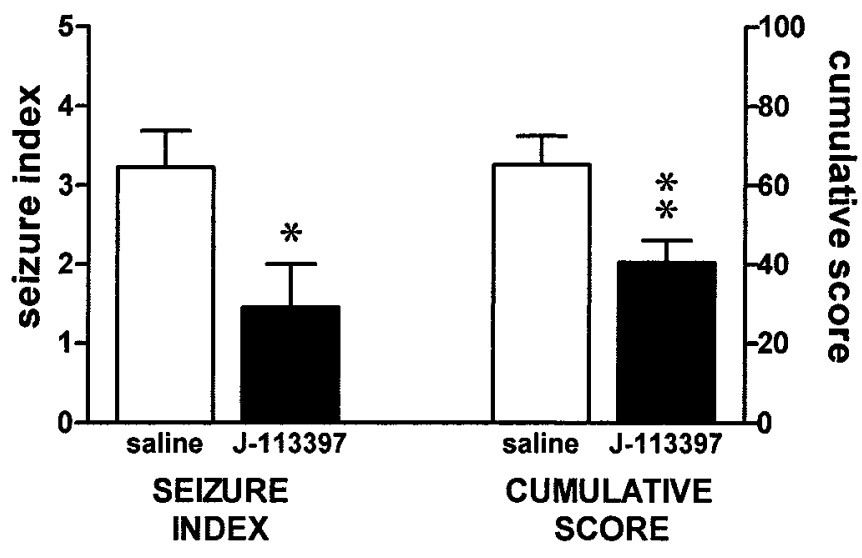

N/OFQ KO

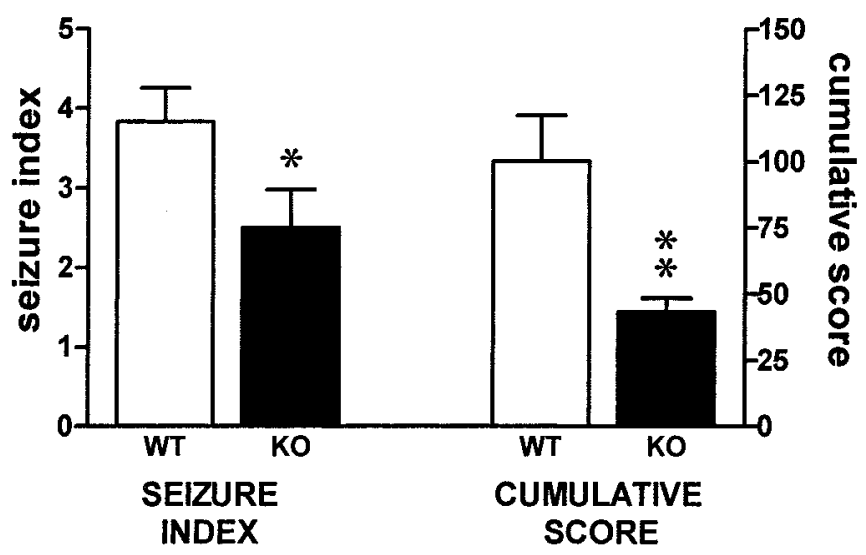

Figure 7. Effect of the NOP receptor antagonist J-113397 (10 nmol, i.c.v.) on kainate seizures in the mouse (top panel) and kainate seizure susceptibility in proN/OFQ knock-out mice (bottom panel). The seizure index was rated according to the following arbitrary scale (Mulle et al., 1998): 0, no seizure; 1 , 1 severe (class 4-5) seizure; 2, 2-5 severe seizures; $3,6-10$ severe seizures; $4,>10$ severe seizures, or very severe seizures (class 6-7); 5, death within $2 \mathrm{hr}$. The cumulative score was rated as the sum of the scores recorded in each 5 min interval of the $2 \mathrm{hr}$ after kainate injection. Seizures have been scored as described in Materials and Methods (Janumpalli et al., 1998). WT, Wild-type mice; $K O$, knock-out mice. Data are the mean \pm SE of 10 animals per group. ${ }^{*} p<0.05 ;{ }^{*} p<0.01$; Mann-Whitney $U$ test.

tion is consistent with a reported opioid receptor turnover time of 3-4 d in vivo (Pasternak, 1993). Although no estimate is available of the turnover rate of NOP receptors specifically, it is likely that it will be similar to one of the other opioid receptors. In fact, as for other opioid receptors (Pasternak and Standifer, 1995), a $5 \mathrm{~d}$ treatment with antisense oligodeoxynucleotides is sufficient to block N/OFQ-induced effects (Leventhal et al., 1998).

Neuronal loss after status epilepticus (Schmued and Hopkins, 2000) may play a role in the reduction of NOP receptor density, especially in the hippocampus. However, we also observed decreased NOP mRNA levels in dentate gyrus granule cells (i.e., a seizure-resistant cell population) and coordinated decrease in NOP mRNA and receptor density in areas (thalamus, cortex) not associated with massive neuronal loss. Therefore, in these other areas, the reduction in receptor density appears to be driven at least partly by regulation at the nuclear level and may represent a response of the N/OFQ system to kainate-induced N/OFQ release, which would make high amounts of agonist available at the receptor level. Indeed, downregulation of NOP receptors in response to agonist stimulation has been described in vivo (Dautzenberg et al., 2001). It is also possible that receptor desensitization and internalization occur at earlier time points (Ma et al., 1997; Dautzenberg et al., 2001; Spampinato et al., 2001).

It is worth noting that increased N/OFQ biosynthesis occurs in more restricted areas than NOP downregulation. Among the regions examined, significantly increased proN/OFQ mRNA levels have been found only in the reticular nucleus of the thalamus and in the medial nucleus of the amygdala, although NOP receptor downregulation was observed in many, widespread areas. These observations confirm and extend a previous report (Bregola et al., 1999). Mismatches between the neurotransmitter and the receptor distributions, like those observed in this study, are quite common and indicate that neurons producing N/OFQ in one area project their terminals (finding specific receptors) in neighboring areas. The reticular thalamic nucleus contains high proN/OFQ mRNA and N/OFQ peptide levels and moderate NOP receptor mRNA expression and binding (Neal et al., 1999a,b). Within the thalamus, we found that proN/OFQ increases selectively in the reticular nucleus, whereas NOP decreases diffusely, in various nuclei. This suggests that the cell bodies of N/OFQ neurons are in the reticular nucleus, whereas their terminals project to various thalamic nuclei. Indeed, thalamocortical cells in each nucleus of the thalamus project to the cortex and to a restricted part of the thalamic reticular nucleus, which projects back to that specific nucleus. Thus, $\mathrm{N} / \mathrm{OFQ}$ may be involved in the modulation of thalamocortical circuits (Neal et al., 1999b). In the amygdala, levels of proN/OFQ mRNA and N/OFQ peptide immunoreactivity are high in the medial and central nucleus, whereas NOP mRNA levels and receptor binding are negligible in the central but dense in the medial nucleus (Neal et al., 1999a,b). The presence of the N/OFQ-NOP system in these structures may underlie an influence in many functions, including seizures (Hosford et al., 1995).

Kainate receptor representation and seizure-induced neuronal hyperactivity do not appear to be the only factors conditioning the adaptations in the N/OFQ-NOP system. For example, kainate receptors are expressed more intensely in the dentate gyrus of the hippocampus than in the thalamic reticular nucleus (Wisden and Seeburg, 1993), and limbic seizures cause much more intense activation of hippocampal granule cells (McNamara, 1988) than of thalamic reticular neurons (White and Price, 1993; Zhang et al., 1997). Yet we found greater changes in the thalamic than in the hippocampal N/OFQ-ORL1 system. Subtle differences in the molecular composition of kainate receptors (Wisden and Seeburg, 1993) and in the pattern of neuronal firing (McNamara, 1988; Guillery et al., 1998) between the dentate gyrus and the thalamic reticular nucleus may account for this unexpected observation.

In summary, proN/OFQ and NOP gene expression and binding data suggest that limbic seizures may be associated with increased N/OFQ release, causing downregulation of NOP receptors and activation of N/OFQ biosynthesis in selected areas (amygdala and thalamus more than hippocampus).

\section{Physiopathological implications}

What may be the role of released N/OFQ in seizure expression? Clues to answer this question have been given initially by release and electrophysiological studies, which provided information on 
the basic effects of N/OFQ in the modulation of excitability. Focusing on the areas examined in this study, we find the following: in the cortex, N/OFQ inhibits norepinephrine (Schlicker et al., 1998), serotonin (Siniscalchi et al., 1999; Werthwein et al., 1999), and glutamate release [from slices (Nicol et al., 1996) but not from synaptosomes (Sbrenna et al., 1999)], whereas it does not affect acetylcholine (Schlicker et al., 1998) and GABA (Sbrenna et al., 1999) release; in the hippocampus, N/OFQ inhibits norepinephrine release (Werthwein et al., 1999) and excitatory neurotransmission (Madamba et al., 1999; Moran et al., 2000); in the amygdala, N/OFQ inhibits GABA and glutamate release (Meis and Pape, 2001); and in the thalamus, N/OFQ decreases the firing rate in a subset of neurons but increases it in another subset (Albrecht et al., 2001). Thus, N/OFQ exerts inhibitory effects on neurotransmitter release, with relevant differences in efficiency depending on the neurotransmitter and the brain area. On the basis of these findings, it is difficult to speculate about pro- or anti-seizure effects of the peptide. For example, although inhibition of the glutamate signal in these brain areas associates with anti-seizure effects (Dingledine et al., 1990), inhibition of the GABA (Treiman, 2001) and norepinephrine (Weinshenker et al., 2001) signal correlates with proseizure effects. Therefore, the net effect of N/OFQ may depend on the circuitries involved in the generation or amplification of the specific type of seizure. For example, N/OFQ would be expected to play an anti-seizure role in the hippocampus, and this has been confirmed recently for epileptiform events generated in isolated hippocampal slices (Tallent et al., 2001).

But what will be the role of N/OFQ in seizures elicited in the intact animal? Thus far, this question has been challenged using NOP agonists, with conflicting, inconclusive results (Mathis et al., 1998; Jenck et al., 2000; Gutierrez et al., 2001). Thus, we thought to investigate this problem by using two diverse, complementary approaches. The first, a pharmacological approach, consists of the use of an NOP receptor antagonist. We chose to use an antagonist rather than an agonist because the goal was to examine the role of endogenous N/OFQ. We used a potent and selective nonpeptidic NOP receptor antagonist, J-113397 (Ozaki et al., 2000). However, the pharmacological profile of this compound (in particular, its specificity) is still not known completely. Therefore, we thought to associate a second, genetic approach using proN/OFQ knockout mice (Köster et al., 1999). These mice display increased anxiety-like behavior, elevated basal pain threshold, and impaired adaptation to repeated stress (Köster et al., 1999), as expected on the basis of N/OFQ effects (Calò et al., 2000). However, as for any knock-out animal, functional compensations resulting from the chronic absence of the gene may have occurred during development, with the potential to mask some of the phenotypes. The different limitations of pharmacology and genetics stress the value of our combined approach. In the kainate model, we have found converging evidence for a pro-seizure effect of endogenous N/OFQ, in that susceptibility to seizures was decreased both in J-113397-treated and in proN/OFQ knock-out mice. Importantly, N/OFQ administration to knock-out animals restored a normal susceptibility to kainate, indicating that the absence of N/OFQ and not of other bioactive peptides coded by proN/OFQ such as nocistatin (Okuda-Ashitaka et al., 1998) or developmental compensatory changes in other systems account for the phenotype observed.

In this study, however, we have focused on a model of acute seizures, and further investigation will be required to characterize the involvement of the N/OFQ-NOP system in epilepsy. Taken together with other reports (Gutierrez et al., 2001; Tallent et al., 2001), the present data suggest that the role of N/OFQ during seizures is complex, with different effects in different seizure and epilepsy types. Therefore, a careful examination of the precise indications of drugs affecting the N/OFQ-NOP system in the different epilepsy types is highly warranted.

\section{REFERENCES}

Albrecht D, Bluhdorn R, Siegmund H, Berger H, Calò G (2001) Inhibitory action of nociceptin/orphanin FQ on functionally different thalamic neurons in urethane-anaesthetized rats. $\mathrm{Br} \mathrm{J}$ Pharmacol 134:333-342.

Bregola G, Candeletti S, Romualdi P, Simonato M (1999) Limbic seizures increase pronociceptin mRNA levels in the thalamic reticular nucleus. NeuroReport 10:541-546.

Bunzow JR, Saez C, Mortrud M, Bouvier C, Williams JT, Low M, Grandy DK (1994) Molecular cloning and tissue distribution of a putative member of the rat opioid receptor gene family that is not a $\mu, \delta$ or $\kappa$ opioid receptor type. FEBS Lett 347:284-288.

Calò G, Guerrini R, Rizzi A, Salvadori S, Regoli D (2000) Pharmacology of nociceptin and its receptor: a novel therapeutic target. $\mathrm{Br} \mathrm{J}$ Pharmacol 129:1261-1283.

Chen Y, Fan Y, Liu J, Mestak A, Tian M, Kozak CA, Yu L (1994) Molecular cloning tissue distribution and chromosomal localization of a novel member of the opioid receptor gene family. FEBS Lett 347:279-283.

Chomczynski P, Sacchi N (1987) Single-step method of RNA isolation by acid guanidinium thiocyanate-phenol-chloroform extraction. Anal Biochem 162:156-159.

Cox BM, Chavkin C, Christie MJ, Civelli O, Evans C, Hamon MD, Hollt V, Kieffer B, Kitchen I, McKnight AT, Meunier JC, Portoghese PS (2000) Opioid receptors. In: The IUPHAR compendium of receptor characterization and classification (Girdlestone D, ed), pp 321-333. London: IUPHAR Media.

Dautzenberg FM, Wichmann J, Higelin J, Py-Lang G, Kratzeisen C, Malherbe P, Kilpatrick GJ, Jenck F (2001) Pharmacological characterization of the novel nonpeptide orphanin $\mathrm{FQ} /$ nociceptin receptor agonist Ro 64-6198: rapid and reversible desensitization of the ORL1 receptor in vitro and lack of tolerance in vivo. J Pharmacol Exp Ther 298:812-819.

De Risi C, Pollini GP, Trapella C, Peretto I, Ronzoni S, Giardina GA (2001) A new synthetic approach to 1-[(3R, 4R)-1-cyclooctylmethyl-3hydroxymethyl-4-piperidyl]-3-ethyl-1, 3-dihydro-benzimidazol-2-one (J-113397), the first non-peptide ORL-1 receptor antagonist. Bioorg Med Chem 9:1871-1877.

Dingledine R, McBain CJ, McNamara JO (1990) Excitatory amino acid receptors in epilepsy. Trends Pharmacol Sci 11:334-338.

Fukuda K, Kato S, Mori K, Nishi M, Takeshima H, Iwabe N, Miyata T, Houtani T, Sugimoto T (1994) cDNA cloning and regional distribution of a novel member of the opioid receptor family. FEBS Lett 343:42-46.

Grisel JE, Mogil JS (2000) Effects of supraspinal orphanin FQ/nociceptin. Peptides 21:1037-1045.

Guillery RW, Feig SL, Lozsadi DA (1998) Paying attention to the thalamic reticular nucleus. Trends Neurosci 21:28-32.

Gunning P, Ponte P, Okayama H, Engel J, Blau H, Kedes L (1983) Isolation and characterization of full-length cDNA clones for human alpha-, beta-, and gamma-actin mRNAs: skeletal but not cytoplasmic actins have an amino-terminal cysteine that is subsequently removed. Mol Cell Biol 3:787-795.

Gutierrez R, Leff P, Romo-Parra H, Acevedo R, Anton B (2001) Orphanin-FQ/nociceptin inhibits kindling epileptogenesis and enhances hippocampal feed-forward inhibition. Neuroscience 105:325-333.

Hokfelt T (1991) Neuropeptides in perspective: the last ten years. Neuron 7:867-879.

Hosford DA, Simonato M, Cao Z, Garcia-Cairasco N, Silver JM, Butler L, Shin C, McNamara JO (1995) Differences in the anatomic distribution of immediate-early gene expression in amygdala and angular bundle kindling development. J Neurosci 15:2513-2523.

Janumpalli S, Butler LS, MacMillan LB, Limbird LE, McNamara JO (1998) A point mutation (D79N) of the $\alpha 2 \mathrm{~A}$ adrenergic receptor abolishes the anti-epileptogenic action of endogenous norepinephrine. J Neurosci 18:2004-2008.

Jenck F, Moreau JL, Martin JR, Kilpatrick GJ, Reinscheid RK, Monsma FJ, Nothacker HP, Civelli O (1997) Orphanin FQ acts as an anxiolytic to attenuate behavioral responses to stress. Proc Natl Acad Sci USA 94:14854-14858.

Jenck F, Wichmann J, Dautzenberg FM, Moreau JL, Ouagazzal AM, Martin JR, Lundstrom K, Cesura AM, Poli SM, Roever S, Kolczewski S, Adam G, Kilpatrick G (2000) A synthetic agonist at the orphanin FQ/nociceptin receptor ORL1: anxiolytic profile in the rat. Proc Natl Acad Sci USA 97:4938-4943.

Kawamoto H, Ozaki S, Itoh Y, Miyaji M, Arai S, Nakashima H, Kato T, 
Ohta H, Iwasawa Y (1999) Discovery of the first potent and selective small molecule opioid receptor-like (ORL1) antagonist: 1-[(3R, 4R)-1cyclooctylmethyl-3-hydroxymethyl-4-piperidyl]-3-ethyl-1, 3-dihydro2H-benzimidazol-2-one (J-113397). J Med Chem 42:5061-5063.

Köster A, Montkowski A, Schulz S, Stube EM, Knaudt K, Jenck F, Moreau JL, Nothacker HP, Civelli O, Reinscheid RK (1999) Targeted disruption of the orphanin FQ/nociceptin gene increases stress susceptibility and impairs stress adaptation in mice. Proc Natl Acad Sci USA 96:10444-10449.

Lachowicz JE, Shen Y, Monsma FJ, Sibley DR (1995) Molecular cloning of a novel $G$ protein-coupled receptor related to the opiate receptor family. J Neurochem 64:34-40.

Laursen SE, Belknap JK (1986) Intracerebroventricular injections in mice. Some methodological refinements. J Pharmacol Methods 16:355-357.

Leventhal L, Mathis JP, Rossi GC, Pasternak GW, Bodnar RJ (1998) Orphan opioid receptor antisense probes block orphanin FQ-induced hyperphagia. Eur J Pharmacol 349:R1-3.

Lowry OH, Rosebrough NJ, Farr A, Randall RJ (1951) Protein measurement with the Folin phenol reagent. J Biol Chem 193:265-275.

Ma L, Cheng ZJ, Fan GH, Cai YC, Jiang LZ, Pei G (1997) Functional expression, activation and desensitization of opioid receptor-like receptor ORL1 in neuroblastoma $\mathrm{x}$ glioma NG108-15 hybrid cells. FEBS Lett 403:91-94.

Madamba SG, Schweitzer P, Siggins GR (1999) Nociceptin augments $\mathrm{K}(+)$ currents in hippocampal CA1 neurons by both ORL-1 and opiate receptor mechanisms. J Neurophysiol 82:1776-1785.

Manabe T, Noda Y, Mamiya T, Katagiri H, Houtani T, Nishi M, Noda T, Takahashi T, Sugimoto T, Nabeshima T, Takeshima H (1998) Facilitation of long-term potentiation and memory in mice lacking nociceptin receptors. Nature 394:577-581.

Mathis JP, Goldberg IE, Rossi GC, Leventhal L, Pasternak GW (1998) Antinociceptive analogs of orphanin FQ/nociceptin(1-11). Life Sci 63:161-166.

McNamara JO (1988) Pursuit of the mechanism of kindling. Trends Neurosci 11:33-36.

Meis S, Pape HC (2001) Control of glutamate and GABA release by nociceptin/orphanin FQ in the rat lateral amygdala. J Physiol (Lond) 532:701-712.

Meunier JC, Mollereau C, Toll L, Suaudeau C, Moisand C, Alvinerie P, Butour JL, Guillemot JC, Ferrara P, Monsarrat B, Mazarguil H, Vassart G, Parmentier M, Costentin J (1995) Isolation and structure of the endogenous agonist of opioid receptor-like ORL1 receptor. Nature $377: 532-535$

Mollereau C, Parmentier M, Mailleux P, Butour JL, Moisand C, Chalon P, Caput D, Vassart G, Meunier JC (1994) ORL1, a novel member of the opioid receptor family. Cloning, functional expression and localization. FEBS Lett 341:33-38.

Moran TD, Abdulla FA, Smith PA (2000) Cellular neurophysiological actions of nociceptin/orphanin FQ. Peptides 21:969-976.

Mulle C, Sailer A, Perez-Otano I, Dickinson-Anson H, Castillo PE, Bureau I, Maron C, Gage FH, Mann JR, Bettler B, Heinemann SF (1998) Altered synaptic physiology and reduced susceptibility to kainate-induced seizures in GluR6-deficient mice. Nature 392:601-605.

Neal Jr CR, Mansour A, Reinscheid R, Nothacker HP, Civelli O, Watson Jr SJ (1999a) Localization of orphanin FQ (nociceptin) peptide and messenger RNA in the central nervous system of the rat. J Comp Neurol 406:503-547.

Neal Jr CR, Mansour A, Reinscheid R, Nothacker HP, Civelli O, Akil H, Watson Jr SJ (1999b) Opioid receptor-like (ORL1) receptor distribution in the rat central nervous system: comparison of ORL1 receptor mRNA expression with ${ }^{125} \mathrm{I}-\left[{ }^{14} \mathrm{Tyr}\right]$-orphanin FQ binding. J Comp Neurol 412:563-605.

Nicol B, Lambert DG, Rowbotham DJ, Smart D, McKnight AT (1996) Nociceptin induced inhibition of $\mathrm{K}+$ evoked glutamate release from rat cerebrocortical slices. Br J Pharmacol 119:1081-1083.

Okuda-Ashitaka E, Minami T, Tachibana S, Yoshihara Y, Nishiuchi Y, Kimura T, Ito S (1998) Nocistatin, a peptide that blocks nociceptin action in pain transmission. Nature 392:286-289.

Ozaki S, Kawamoto H, Itoh Y, Miyaji M, Azuma T, Ichikawa D, Nambu $\mathrm{H}$, Iguchi T, Iwasawa Y, Ohta $\mathrm{H}$ (2000) In vitro and in vivo pharmacological characterization of J-113397, a potent and selective nonpeptidyl ORL1 receptor antagonist. Eur J Pharmacol 402:45-53.

Pan Y-H, Cheng J, Xu J, Rossi G, Jacobson E, Ryan-Moro J, Brooks AI, Dean GE, Standifer KM, Pasternak GW (1995) Cloning and functional characterization through antisense mapping of a $\mathrm{k}_{\mathrm{s}}$-related opioid receptor. Mol Pharmacol 47:1180-1188.

Pasternak GW (1993) Pharmacological mechanisms of opioid analgesics. Clin Neuropharmacol 16:1-18.

Pasternak GW, Standifer KM (1995) Mapping of opioid receptors using antisense oligodeoxynucleotides: correlating their molecular biology and pharmacology. Trends Pharmacol Sci 16:344-350.

Pellegrino LJ, Pellegrino AS, Cushman AJ (1979) A stereotaxic atlas of the rat brain. New York: Plenum.
Reinscheid RK, Nothacker HP, Bourson A, Ardati A, Henningsen RA, Bunzow JR, Grandy DK, Langen H, Monsma FJ Jr, Civelli O (1995) Orphanin FQ: a neuropeptide that activates an opioidlike $\mathrm{G}$ proteincoupled receptor. Science 270:792-794.

Rocha LL, Evans CJ, Maidment NT (1997) Amygdala kindling modifies extracellular opioid peptide content in rat hippocampus measured by microdialysis. J Neurochem 68:616-624.

Romualdi P, Donatini A, Bregola G, Bianchi C, Beani L, Ferri S, Simonato M (1995) Early changes in prodynorphin mRNA and irdynorphin A levels after kindled seizures in the rat. Eur J Neurosci 7:1850-1856.

Sandin J, Georgieva J, Schott PA, Ogren SO, Terenius L (1997) Nociceptin/orphanin FQ microinjected into hippocampus impairs spatial learning in rats. Eur J Neurosci 9:194-197.

Sbrenna S, Marti M, Morari M, Calò G, Guerrini R, Beani L, Bianchi C (1999) L-glutamate and gamma-aminobutyric acid efflux from rat cerebrocortical synaptosomes: modulation by kappa- and mu- but not delta- and opioid-receptor like-1 receptors. J Pharmacol Exp Ther 291:1365-1371.

Schlicker E, Morari M (2000) Nociceptin/orphanin FQ and neurotransmitter release in the central nervous system. Peptides 21:1023-1029.

Schlicker E, Werthwein S, Kathmann M, Bauer U (1998) Nociceptin inhibits noradrenaline release in the mouse brain cortex via presynaptic ORL1 receptors. Naunyn Schmiedebergs Arch Pharmacol 358:418-422.

Schmued LC, Hopkins KJ (2000) Fluoro-Jade B: a high affinity fluorescent marker for the localization of neuronal degeneration. Brain Res 874:123-130.

Simonato M, Romualdi P (1996) Dynorphin and epilepsy. Prog Neurobiol 50:557-583.

Simonato M, Bregola G, Donatini A, Bianchi C, Beani L, Ferri S, Romualdi P (1996) Kindled seizure-induced c-fos and prodynorphin mRNA expressions are unrelated in the rat brain. Eur J Neurosci 8:2064-2067.

Siniscalchi A, Rodi D, Beani L, Bianchi C (1999) Inhibitory effect of nociceptin on $\left[{ }^{3} \mathrm{H}\right]-5$-HT release from rat cerebral cortex slices. $\mathrm{Br} \mathrm{J}$ Pharmacol 128:119-123.

Spampinato S, Di Toro R, Qasem AR (2001) Nociceptin-induced internalization of the ORL1 receptor in human neuroblastoma cells. NeuroReport 12:3159-3163.

Tallent MK, Madamba SG, Siggins GR (2001) Nociceptin reduces epileptiform events in CA3 hippocampus via presynaptic and postsynaptic mechanisms. J Neurosci 21:6940-6948.

Tian JH, Zhang W, Fang Y, Xu W, Grandy DK, Han JS (1998) Endogenous orphanin FQ: evidence for a role in the modulation of electroacupuncture analgesia and the development of tolerance to analgesia produced by morphine and electroacupuncture. $\mathrm{Br} \mathrm{J}$ Pharmacol 124:21-26.

Treiman DM (2001) GABAergic mechanisms in epilepsy. Epilepsia 42(S3):8-12.

Wang J-B, Johnson PS, Imai Y, Persico AM, Ozenberger BA, Eppler CM, Uhl G (1994) cDNA cloning of an orphan opiate receptor gene family member and its splice variant. FEBS Lett 348:75-79.

Weinshenker D, Szot P, Miller NS, Rust NC, Hohmann JG, Pyati U, White SS, Palmiter RD (2001) Genetic comparison of seizure control by norepinephrine and neuropeptide Y. J Neurosci 21:7764-7769.

Werthwein S, Bauer U, Nakazi M, Kathmann M, Schlicker E (1999) Further characterization of the ORL1 receptor-mediated inhibition of noradrenaline release in the mouse brain in vitro. $\mathrm{Br} \mathrm{J}$ Pharmacol 127:300-308.

White LE, Price JL (1993) The functional anatomy of limbic status epilepticus in the rat. I. Patterns of 14C-2-deoxyglucose uptake and Fos immunocytochemistry. J Neurosci 13:4787-4809.

Wick MJ, Minnerath SR, Lin X, Elde R, Law PY, Loh HH (1994) Isolation of a novel cDNA encoding a putative membrane receptor with high homology to the cloned mu, delta, and kappa opioid receptors. Mol Brain Res 27:37-44.

Wick MJ, Minnerath SR, Roy S, Ramakrishnan S, Loh HH (1995) Expression of alternate forms of brain opioid orphan receptor mRNA in activated human peripheral blood lymphocytes and lymphocytic cell lines. Mol Brain Res 32:342-347.

Wisden W, Seeburg PH (1993) A complex mosaic of high-affinity kainate receptors in rat brain. J Neurosci 13:3582-3598.

Xie GX, Meuser T, Pietruck C, Sharma M, Palmer PP (1999) Presence of opioid receptor-like (ORL1) receptor mRNA splice variants in peripheral sensory and sympathetic neuronal ganglia. Life Sci 64:2029-2037.

Yu TP, Xie CW (1998) Orphanin FQ/nociceptin inhibits synaptic transmission and long-term potentiation in rat dentate gyrus through postsynaptic mechanisms. J Neurophysiol 80:1277-1284.

Zhang X, Le Gal La Salle G, Ridoux V, Yu PH, Ju G (1997) Protection of kainic acid-induced limbic seizures and Fos expression by the GABA-A receptor agonist muscimol. Eur J Neurosci 9:29-40. 